Available Online at https://journal.unismuh.ac.id/index.php/otoritas

Otoritas : Jurnal Ilmu Pemerintahan, 9 (2), October 2019, 162-178

\title{
How Does Public Service Motivation Contribute to Service Orientation? Testing Mediation Models
}

\author{
Wayu Eko Yudiatmaja*) \\ Department of Public Administration, Faculty of Social and Political Sciences, \\ Universitas Maritim Raja Ali Haji, Jl. Raya Dompak, Tanjungpinang 29111, Indonesia.
}

Received: 6 July 2019; Revised: 27 September 2019; Accepted: 30 September 2019

\begin{abstract}
Public service motivation is an emerging topic in the study of public administration, but no study has adequately investigated how it affects employee service orientation through job satisfaction and organizational commitment. The present study is ultimately aimed to fill the research gap by examining whether public service motivation influences service orientation and if so, whether the effect is mediated by job satisfaction and organizational commitment. Data were analyzed by using WarpPLS 6.0. Using a sample of 160 public servants in the city government of Tanjungpinang, the results indicate that employee service orientation is directly and positively affected by PSM. In addition, public service motivation also has an indirect impact on employee service orientation through job satisfaction and organizational commitment. Furthermore, the theoretical and practical implications of the study for human resources management in the public sector are discussed.
\end{abstract}

Keywords: Public Service Motivation; Job Satisfaction; Organizational Commitment; Service Orientation

How to Cite: Yudiatmaja, W. E. (2019). How Does Public Service Motivation Contribute to Service Orientation? Testing Mediation Models. Otoritas : Jurnal Ilmu Pemerintahan, 9(2), 162-178.

Permalink/DOI: https://doi.org/10.26618/ojip.v9i2.2180

${ }^{*}$ Corresponding Author.

E-Mail : wayuguci@umrah.ac.id

Copyright (C) 2019, Otoritas : Jurnal Ilmu Pemerintahan, ISSN: 2088-3706 (Print), ISSN: 2502-9320 (Online) 
Available Online at https://journal.unismuh.ac.id/index.php/otoritas

Otoritas : Jurnal Ilmu Pemerintahan, 9 (2), October 2019, 163

\section{INTRODUCTION}

Public service motivation (PSM) was first acknowledged in the public service ethics debate, whereby public and private workers were differentiated toward motivation for recompenses (Buchanan, 1975; Rainey, 1982). Actually, PSM related to the willingness to oblige the public entirely (Perry \& Wise, 1990). Unlike the cohort of extrinsic motivation, PSM theorists believe that motivation of the employees is driven by intrinsic rather than extrinsic motivation (Horton \& Hondeghem, 2006; Park \& Word, 2012). The motivation to help the public emerge from individual calling and personal desire, like benevolent patriotism (Frederickson \& Hart, 1985), helping others and community (Lewis \& Frank, 2002), self-sacrifice, compassion, and civic duty (Clerkin \& Coggburn, 2012).

Theoretically, PSM slightly relates to the public sector employees' service orientation. Several contemporary studies confirm this argument; for instance, Christensen \& Wright (2011) noted that PSM increased public employees' motivation to join in the public sector only when their job is service-oriented. In the context of the Danish government, Andersen \& Pedersen (2012) pointed out that public service providers in the Danish government related to user orientation.

Sayce (2016) also highlighted that PSM affected the user orientation of pension trustees in the UK. In sum, the prior research highlighted the crucial role of PSM in upgrading the positive attitudes of the public employees to serving people. Public workers with precisely PSM tend to attract a behavior to prioritize the interest to assist the public.

Prior studies also emphasize that PSM correlates with behaviors and attitudes in the workplace, specifically work satisfaction, commitment to the organization, and job performance. Vandenabeele (2009) proved based on empirical find- ings in Belgian civil servants that PSM had a favorable connection with job contentment, organizational commitment, and individual performance. Liu, Tang, \& Yang (2015) investigated more than 600 public employees in China and showed that the increase of PSM, individual-organization fit, and demands-supplies fit follow with intensifying of the employee job satisfaction.

Other studies provide a conceptual framework linking work satisfaction and organizational commitment on service orientation. Korunka et al. (2007) claimed that work characteristics, characteristics of the organization, and working life quality related to the customer orientation of employees. Kelley (1992) studied the effect of organizational socialization, organizational climate, and organizational commitment on customer orientation of service employees in the financial institutions. He suggested that not only organizational socialization but also organizational commitment affects customer orientation.

Based upon the theoretical review above, PSM directly relates to the service orientation. PSM also is associated with service orientation indirectly through work satisfaction and commitment to the organization. As a result, the eight hypotheses of the current study can be formulated as follows: (1) PSM positively relates to job satisfaction; (2) PSM positively affects organizational commitment; (3) There is a positive link between PSM and service orientation; (4) Job satisfaction has a positive and significant influence on commitment to the organization; (5) Job satisfaction influences service orientation; (6) Organizational commitment positively affects service orientation; (7) The link between PSM and service orientation is mediated by job satisfaction; (8) The connection between PSM and service orientation is mediated by commitment to the organization.

This study provides a novelty to 
the literature of PSM in three respects. First, there is a research of PSM and user orientation previously (Andersen \& Kjeldsen, 2013; Jensen \& Andersen, 2015), but the focus of this inquiry is the nexus between PSM and service orientation. Second, prior studies have tested the association of PSM with job satisfaction (Kjeldsen \& Hansen, 2018; Naff \& Crum, 1999; Taylor, 2014; Taylor \& Westover, 2011) and organizational commitment (Caillier, 2015; Castaing, 2006; Jin, McDonald, \& Park, 2018; Kim, 2017; Potipiroon \& Ford, 2017) of the public employees. We have a lack of empirical evidence investigating the links of job satisfaction and organizational commitment as mediating variables between the relationship of PSM and service orientation. Thus, the present research fills the gap by examining the role of two mediating variables, which are job satisfaction and organizational commitment. Third, much of the empirical analysis examines the PSM in the context of western or developed countries, which has contextual differences with developing countries (Van der Wal, 2015; Yudiatmaja, 2012, 2017). Hence, unlike most inquiries, the current study investigates the public servants in the Indonesian local government.

The structure of this paper is proposed in the following manner. The reviews of the literature related to the study are introduced to this passage. This part contains numerous hypotheses based on previous investigations and theoretical bases. The research approach and data analysis method are presented in the subsequent section. Then, the study's findings and implications are discussed. Eventually, the resume of the study is addressed in the conclusion of the article.

\section{RESEARCH METHODS}

A survey approach was applied in the current research to examine the proposed hypotheses. Although Perry (1996, 1997) had developed the PSM construct, this study used Cun's (2012) items of PSM because it was more contextual for this research. Following Spector (1985), Job Satisfaction Survey (JSS) indicators were used in the research to measure employees' job satisfaction. To examine organizational commitment, this research adapted organizational commitment items from Allen \& Meyer (1990). A series of customer orientation evolved by Susskind, Kacmar, \& Borchgrevink (2003) was utilized to assess employee service orientation validated by the diverse of previous studies (Chiang \& Birtch, 2011; Liaw, Chi, \& Chuang, 2010). All of the items initially used English, and it was translated into Bahasa Indonesia by performing back-toback translation strictly. In order to ask the participants to consider all of the variables of this research, the five points of the Likert-scale from strongly disagree (1) to strongly agree (5) were utilized.

By using a self-administered survey, data in this study were gathered from civil servants serving in the city government of Tanjungpinang, Kepulauan Riau. It was randomly chosen 250 public servants as a sample of this study. In total, 160 participants were returning the questionnaire (a 64\% response rate). Demographic variable showed that male respondent $(58.1 \%)$ was larger than female. About $42.5 \%$ of the respondents had a graduated educational background. More than two-thirds of the respondent was a permanent employee (68.8\%) with 14-22 years of the average of working experience.

To achieve the intention of this study, the data were analyzed in three steps. First, descriptive analysis and correlations among the variables of the research were employed to determine the mean, standard deviation, and squared root of AVE. Second, a linear regression was practiced to verify the research hypotheses. Eventually, a series of mediating tests were applied to test the effect of the mediators' variables in the nexus be- 
tween the independent and dependent variables. A Sobel test was practiced to seek mediating effects (Hayes, 2009).

This study consisted of independent, dependent, and mediating variables. The main independent variable was PSM; the primary dependent variable was employee service orientation; and job satisfaction and organizational commitment role as intervening variables. The proposed hypotheses and conceptual model of the study were illustrated, as shown in Figure 1.

\section{RESULTS AND DISCUSSION}

\section{Descriptive Statistics}

The results of the descriptive statistics of the studied variables involving theoretical and real values of mean, minimum, maximum, and the standard deviation are presented in Table 1 . It demonstrates that while there is a wide variety of answers, the means indicate that the sampled participants tended to heavily job satisfaction (4.24) and thought their PSM is high (4.17). The level of organizational commitment (4.11) and service orientation (4.22) of the civil servants is less strongly rated than two other variables revealing that the employees tend to more interest in their job than their organization. The data also show that the standard deviation of each variable is no more than 1.00 . It reflects that the data are normally distributed in the research sample.

\section{Reliability and Validity}

As priorly explained, firstly model fit and quality indices of the structural model are assessed by examining confirmatory factor analysis (CFA). By using WarpPLS, a CFA reveals the fit model and quality indices of the data in proper range: average R-squared (ARS) $=0.531$, average variance inflation factor (AVIF) $=$ 3.302, average path coefficient (APC) $=$ 0.381, average adjusted R-squared $($ AARS $)=0.525$ (Kline, 2011; Kock, 2011). Consequently, the entire model fits the sample of research data so it can be further analyzed.

Secondly, the reliability and validity aspect are measured by checking the adequacy of reliability and validity (both convergent and discriminant validity) before analyzing the structural model (Anderson \& Gerbing, 1988). To analyze the reliability of the outer models, the loading of the indicators and composite

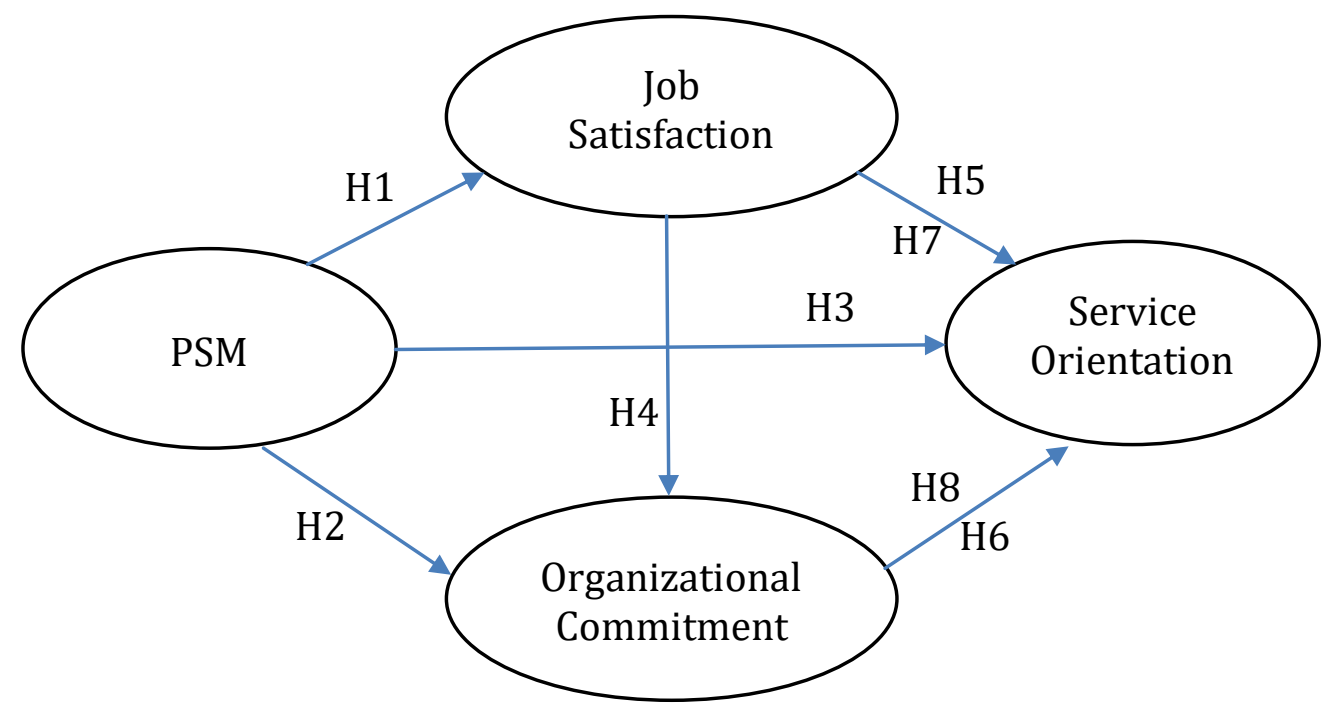

Figure 1. Theoretical Model of the Expected Relationships

Source: Developed from prior studies and the research gaps (2019) 
reliability are assessed. Because the loading factors exceed 0.60 , the indicators in this study are significant. As asserted by Gerbing \& Anderson (1988), the loading factors should be in the range of 0.60 0.70 . The composite reliability is in the acceptable range because of between 0.69 and 0.82 , more than 0.6 encouraged by several scholars (Bagozzi \& Yi, 1988; Fornell \& Larcker, 1981; Hair, Ringle, \& Sarstedt, 2011).

As priorly explained, firstly model fit and quality indices of the structural model are assessed by examining confirmatory factor analysis (CFA). By using WarpPLS, a CFA reveals the fit model and quality indices of the data in proper range: average $\mathrm{R}$-squared (ARS) $=0.531$, average variance inflation factor $(\mathrm{AVIF})=$ 3.302 , average path coefficient $($ APC) $=$ 0.381, average adjusted R-squared (AARS) $=0.525$ (Kline, 2011; Kock, 2011). Consequently, the entire model fits the sample of research data so it can be further analyzed.

Secondly, the reliability and validity aspect are measured by checking the adequacy of reliability and validity (both convergent and discriminant validity) before analyzing the structural model (Anderson \& Gerbing, 1988). To analyze the reliability of the outer models, the loading of the indicators and composite reliability are assessed. Because the loading factors exceed 0.60 , the indicators in this study are significant. As asserted by Gerbing \& Anderson (1988), the loading factors should be in the range of 0.60 0.70 . The composite reliability is in the acceptable range because of between 0.69 and 0.82 , more than 0.6 encouraged by several scholars (Bagozzi \& Yi, 1988; Fornell \& Larcker, 1981; Hair, Ringle, \& Sarstedt, 2011).

Table 3 also summarizes that there is numerous positive and significant correlations among the variables, covering PSM with job satisfaction ( $r=0.656$; $\mathrm{p}<$ $0.001)$, organizational commitment $(\mathrm{r}=$
0.527; $\mathrm{p}<0.001)$, and service orientation ( $r=0.646 ; \mathrm{p}<0.001$ ) indicating that PSM is a pivotal variable in increasing work satisfaction, commitment to the organization and employees service orientation. In addition, the table depicts that employee service orientation is positively associated with job satisfaction $(\mathrm{r}=0.642$; $\mathrm{p}<$ 0.001 ) and organizational commitmen ( $\mathrm{r}$ $=0.579 ; \mathrm{p}<0.001$ ) justifying that service orientation of the employees can be enhanced by improving work satisfaction and organizational commitment. Lastly, the table suggests positively correlation between job satisfaction and organizational commitment $(\mathrm{r}=0.437 ; \mathrm{p}<0.001)$ indicating that job satisfaction may enhance organizational commitment.

Finally, after measuring reliability and validity, descriptive statistics among measures are presented, as shown in Table 2. Mean and standard deviation (SD) among indicators are provided to shed light on the data descriptively. Mean each variable is higher than 4 , except organizational commitment 2 and service orientation 4 at the level 3.96 and 3.89. Indeed, the value of SD is greater than 0.70 . It signifies that the civil servants consider PSM, work satisfaction, and commitment to the organization to associate with service orientation.

\section{Hypothesis Testing}

A partial least squares- structural equation modeling (PLS-SEM) was performed to examine the relationships of the variables. It was used because of two reasons. Firstly, it can address to investigate properly multiple variables, both dependent and independent, simultaneously. Secondly, it was worthwhile to handle the research using a small sample (no more than 250 samples). Lastly, the assumption of a normal distribution did not require by PLS (Chin, 1998; Chin \& Newsted, 1999; Chin \& Todd, 2019). In this study, the WarpPLS 6.0 version is employed (Kock, 2017). 
Available Online at https://journal.unismuh.ac.id/index.php/otoritas

Otoritas : Jurnal Ilmu Pemerintahan, 9 (2), October 2019, 167

Table 1. Descriptive Statistics of the Variable

Source: The results of the test of each variable (2019)

\begin{tabular}{clccccc}
\hline \multirow{2}{*}{ Variable } & \multicolumn{2}{c}{ Theoretical score } & \multicolumn{2}{c}{ Actual score } & Mean & SD \\
& Min & Max & Min & Max & & \\
\hline PSM & 1.00 & 5.00 & 2.00 & 5.00 & 4.17 & 0.79 \\
JS & 1.00 & 5.00 & 2.00 & 5.00 & 4.24 & 0.82 \\
OC & 1.00 & 5.00 & 2.00 & 5.00 & 4.11 & 0.75 \\
SO & 1.00 & 5.00 & 2.00 & 5.00 & 4.02 & 0.80 \\
\hline
\end{tabular}

Note: $\mathrm{PSM}=$ public service motivation; $\mathrm{JS}=$ job satisfaction; $\mathrm{OC}=$ organizational commitment; $\mathrm{SO}=$ service orientation

Table 2. Reliability and Validity Analysis of Each Measure

Source: The results of the measure of validity and reliability by using Warp-PLS (2019)

\begin{tabular}{lccc}
\hline Latent Variable & Mean & S.D. & Loading \\
\hline Public Service Motivation (composite reliability = 0.81; AVE $=0.59$ ) & & \\
Public Service Motivation 1 & 4.29 & 0.71 & 0.69 \\
Public Service Motivation 2 & 4.11 & 0.81 & 0.67 \\
Public Service Motivation 3 & 4.28 & 0.78 & 0.62 \\
Public Service Motivation 4 & 4.30 & 0.76 & 0.61 \\
Public Service Motivation 5 & 4.03 & 0.77 & 0.62 \\
Public Service Motivation 6 & 4.03 & 0.82 & 0.63 \\
Public Service Motivation 7 & 4.17 & 0.82 & 0.64 \\
Job satisfaction (composite reliability = 0.82; AVE = 0.75) & & & \\
Job satisfaction 1 & 4.26 & 0.86 & 0.69 \\
Job satisfaction 2 & 4.34 & 0.73 & 0.61 \\
Job satisfaction 3 & 4.22 & 0.80 & 0.67 \\
Job satisfaction 4 & 4.16 & 0.87 & 0.66 \\
Organizational commitment (composite reliability = 0.74; AVE $=0.68$ ) & & \\
Organizational commitment 1 & 4.30 & 0.73 & 0.65 \\
Organizational commitment 2 & 3.96 & 0.77 & 0.74 \\
Organizational commitment 3 & 4.06 & 0.70 & 0.66 \\
Service orientation (composite reliability = 0.69; AVE = 0.53) & & \\
Service orientation 1 & 4.11 & 0.79 & 0.62 \\
Service orientation 2 & 4.03 & 0.83 & 0.69 \\
Service orientation 3 & 4.03 & 0.74 & 0.64 \\
Service orientation 4 & 3.89 & 0.81 & 0.66 \\
Service orientation 5 & 4.05 & 0.84 & 0.62 \\
\hline
\end{tabular}

Table 3. Discriminant Validity

Source: The results of the measure by using Warp-PLS (2019)

\begin{tabular}{ccccc}
\hline Construct & $\begin{array}{c}\text { Public Service } \\
\text { Motivation }\end{array}$ & $\begin{array}{c}\text { Job } \\
\text { satisfaction }\end{array}$ & $\begin{array}{c}\text { Organizational } \\
\text { commitment }\end{array}$ & $\begin{array}{c}\text { Service } \\
\text { orientation }\end{array}$ \\
\hline $\begin{array}{c}\text { Public Service Motivation } \\
\text { Job satisfaction }\end{array}$ & 0.823 & & & \\
Organizational & $0.656^{* * *}$ & 0.839 & 0.895 & 0.878 \\
$\begin{array}{c}\text { commitment } \\
\text { Service orientation }\end{array}$ & $0.527^{* * *}$ & $0.437^{* * *}$ & $0.579^{* * *}$ & \\
\hline
\end{tabular}

Note: ${ }^{* *} p<0.001$ (one-tailed) 
To evaluate the hypotheses of the research, three-steps procedure as recommended by Baron \& Keany (1986) and Williams, Edwards, \& Vandenberg (2003) are applied, as follows: (1) the nexus between independent (PSM) and dependent variable (service orientation), (2) the relationship between independent variable (PSM) and mediating variables (job satisfaction and organizational commitment), (3) the role of mediating variable (work satisfaction and commitment to the organization) in the connection between independent (PSM) and dependent variable (service orientation).

The results reported in Table 4 Panel B and Figure 2 show that the proposed conceptual model is powerfully supported by the findings of this work. It justifies that both job satisfaction $(\beta=$ $0.87 ; \mathrm{p}=<0.001 ; \mathrm{R} 2=0.76$ ) and organizational commitment are positively affected by PSM $(\beta=0.47 ; \mathrm{p}=<0.001 ; \mathrm{R} 2=$ $0.22)$. Therefore, H1 stating that PSM positively relates to work satisfaction and $\mathrm{H} 2$ suggesting PSM positively impacts organizational commitment are strongly supported. Then, mediating variables are introduced with dependent variable. The findings show that both job satisfaction $(\beta$ $=0.14 ; \mathrm{p}=<0.05 ; \mathrm{R} 2=0.62$ ) and organizational commitment $(\beta=0.25 ; \mathrm{p}=<$ 0.001 ; R2 $=0.62$ ) positively and significantly influence employee service orientation, thereby $\mathrm{H} 5$ and $\mathrm{H} 6$ are accepted.

Another pivotal finding of the regression is the link between the independent and dependent variables. The PLS results give a statistical value, which is $\beta=0.75 ; p=<0.001 ; R 2=0.57$. It concludes that PSM affects employee service orientation directly, as suggested in H3. Eventually, the association between the first and another mediating variable proposed as predicted in $\mathrm{H} 4$ is proved because work satisfaction has a negative relationship and not a significant effect on the commitment to the organization $(\beta=-$ $0.06)$. In other words, lower job satisfac- tion enhances loyalty to the organization, and they are not a relationship.

\section{The Mediating Effects}

Finally, the mediating effects are presented. It is conducted to answer whether the relationship between PSM and service orientation are mediated by work satisfaction and commitment to the organization. From the estimation of the analysis, it can be understood that before and after including intervening variables in the connection between PSM and service orientation remain significant impact, but both job satisfaction and commitment to the organization reduce the effect of the nexus $(\beta)$ between PSM and service orientation from 0.75 to 0.62 (see Table 3 Panel A and Table 4 Panel A). Organizational commitment also decreases the correlation between PSM and service orientation from 0.75 to 0.61 (see Table 3 Panel A and Table 5 Panel B). It means both job satisfaction and commitment to the organization partially mediate the relationship (Baron \& Kenny, 1986). The results of Sobel's tests give $1.78(p<0.1)$ for job satisfaction and $2.99(p<0.01)$ indicating mediation of job satisfaction is statistically significant, thereby hypothesis 7 and hypothesis 8 are supported.

\section{Discussion}

This study claims that PSM affects service orientation. It is in line with prior studies, also finding similar results (Andersen, Pallesen, \& Salomonsen, 2013; Potipiroon, Srisuthisa-ard, \& Faerman, 2019). The finding proves that serviceoriented employees influenced by PSM. It means public employees with a higher level of service orientation extremely related to the inner motives to serve the public interest fully. In other words, the enhancing of PSM dimensions, such as public reason, public heart, and the public norm, will significantly improve the commitment of the public employees to serve the public. 
Available Online at https://journal.unismuh.ac.id/index.php/otoritas

Otoritas : Jurnal Ilmu Pemerintahan, 9 (2), October 2019, 169

Table 4. PLS Results (Path Coefficient, $t$-Statistics, and $R^{2}$ )

Source: The results of the measure of research hypotheses by using Warp-PLS (2019)

\begin{tabular}{|c|c|c|c|}
\hline \multicolumn{4}{|l|}{ Panel A. Direct Effect } \\
\hline \multirow{2}{*}{ Variable } & & & Path to \\
\hline & & & Service orientation \\
\hline Public service motivation & & & $0.75(11.224)^{* * *}$ \\
\hline $\mathrm{R}^{2}$ & & & 0.57 \\
\hline \multicolumn{4}{|l|}{ Panel B. Full Model } \\
\hline \multirow[b]{2}{*}{ Variable } & Path to & & \\
\hline & Job satisfaction & $\begin{array}{l}\text { Organizational } \\
\text { commitment }\end{array}$ & Service orientation \\
\hline Public service motivation & $0.87(13.305)^{* * *}$ & $0.47(6.637)^{* * *}$ & $0.49(6.957)^{* * *}$ \\
\hline Job satisfaction & & $-0.06(-0.814)$ & $0.14(1.836)^{* *}$ \\
\hline Organizational commitment & & & $0.25(3.320)^{* * *}$ \\
\hline $\mathrm{R}^{2}$ & 0.76 & 0.22 & 0.62 \\
\hline
\end{tabular}

Note: ${ }^{* * *} p<0.001$ (one-tailed); ${ }^{* *} p<0.05$ (two-tailed)

Table 5. PLS Results (Path Coefficient, $t$-Statistics, and $R^{2}$ )

Source: The results of the measure of research hypotheses by using Warp-PLS (2019)

\begin{tabular}{lll}
\hline \multicolumn{2}{l}{ Panel A. The Mediating Effect of Job Satisfaction } & \\
\hline \multirow{2}{*}{ Variable } & Path to & \\
\cline { 2 - 3 } & Job satisfaction & Service orientation \\
\hline Public service motivation & $0.87(13.305)^{* * *}$ & $0.62(8.930)^{* * *}$ \\
Job satisfaction & & $0.16(2.093)^{* *}$ \\
$\mathrm{R}^{2}$ & 0.76 & 0.57 \\
\hline Panel B. The Mediating Effect of Organizational Commitment & \\
\hline \multirow{2}{*}{ Variable } & Path to & \\
\cline { 2 - 3 } & Organizational commitment & Service orientation \\
\hline Public service motivation & $0.53(7.479)^{* * *}$ & $0.61(8.833)^{* * *}$ \\
Organizational commitment & & $0.25(3.380)^{* * *}$ \\
$\mathrm{R}^{2}$ & 0.28 & 0.61 \\
\hline
\end{tabular}

Note: ${ }^{* * *} p<0.001$ (one-tailed); ${ }^{* *} p<0.05$ (two-tailed) 
In this study, there is a constructive link between PSM and job satisfaction. PSM has a positive influence on organizational commitment as well as. These conclusions are comparable to the past studies revealing that PSM connected favorably to work satisfaction and organizational commitment of Australian public employees (Taylor, 2007, 2008), Belgium (Vandenabeele, 2009), South Korea (Kim, 2012), and Nepal (Shrestha \& Mishra, 2015). However, these findings show the inconsistency with Xiaohua (2008) pointing out that PSM of Chinese government personnel was not associated with work satisfaction and organizational commitment. It counters Wright \& Pandey (2008) concluding that PSM did not has a direct impact on public employees satisfaction in the United States (Wright \& Pandey, 2008).

The findings of this survey also note that worker service orientation is affected by both work satisfaction and organizational commitment. It is quite different from previous work in the case of the private sector. Several studies in this area frame different constructs with the present study in which job satisfaction and commitment to the organization are positioned as a dependent variable and service orientation as an independent variable. They found out that service orientation is strongly influenced by workers' satisfaction on the assignment and their commitment to the organization (Donavan, Brown, \& Mowen, 2004; Hennig-Thurau, 2004; Kim, Leong, \& Lee, 2005).

The results of the mediation analysis point out that job satisfaction and organizational commitment mediate the influence of PSM on service orientation. It proves that both job satisfaction and commitment to the organization positively relate to the commitment to public affairs. If the public servants have high satisfaction with their job and have full commitment to the organization, they will provide the best service to the customers. These quantitative analyses go beyond Vandenabeele's reports (2009) showing that job satisfaction and organizational commitment mediate the effect of PSM on employee performance.

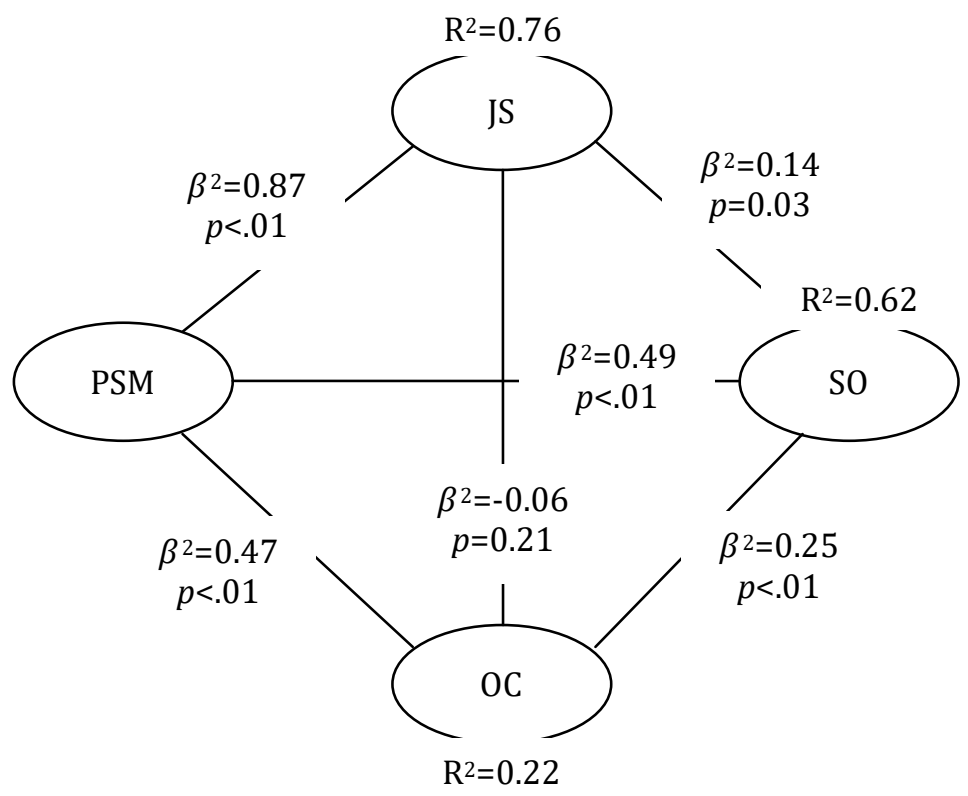

Figure 2. The Results of Hypotheses Examination

Source: Extracted from the results of testing the hypotheses (2019) 
Interestingly, the statistical analysis of this study shows that job satisfaction negatively correlates with organizational commitment. Contrary to the finding of Ismail \& Abd Razak (2016), this work finds that commitment to the organization does not rely on the satisfaction of the employees to their job. Nonetheless, their finding is concluded based on the study in the Fire and Rescue Department of Malaysia, which has a different context with the Indonesian public sector. In the context of Indonesian public service organizations, organizational commitment might be predicted by other factors in the workplace, for instance, organizational culture, leader's style, and employee profiles (e.g., experience, educational background, age, job tenure) (Steijn \& Leisink, 2006).

\section{Limitations and Delimitations}

Besides the expected findings of this study, the constraints of the research should also be noted addressed by further research. First, the empirical results show that service orientation is affected by PSM. This study has not analyzed the other factors of work or organizational outcomes, for example, performance (both individual and organizational) and customer satisfaction. Thus, future studies should address whether the relationship between PSM and performance of government employees can be mediated by service orientation. It is significant to be explored because these questions could extend the theory of PSM and its engagement to different dimensions of organizational consequences (Bright, 2007).

Second, employee service orientation in this study is assessed by self-rating measurement in which respondents were asked to rate their service orientation behavior personally. It can potentially generate a bias in the judgment. To obtain a more objective evaluation of employee service orientation, future research could investigate both the employees and the customers (Hogan, Hogan, \& Busch, 1984; Kelley, 1992). Moreover, further studies could be cross-checked employee service orientation both horizontally and vertically by confirming to the leaders and the customers. In addition, to ensure the objective of the evaluation of the employee's service orientation, this manner could compare the results of every method.

Third, because of the restricted amount of area and participants involved in this study, the generalizability of this study needs to be caution. The future studies should extend the region and participants of the survey, maybe by comparing two cities or more and a larger sample. The subsequent studies can use various methods because this study only uses a single method, which is a survey approach. Recently, research methods in the study of PSM rapidly grow by applying the diversity of methods, such as qualitative and mixed methods (Andersen, Bjørnholt, Bro, \& Holm-Petersen, 2018; Kjeldsen, 2012; Ritz, 2011; Schott, Steen, \& Van Kleef, 2019).

\section{Theoretical and Practical Implications}

Based on the results above, this study implicates on theoretical and practical perspectives to the study of human resources management in the public sector. In terms of theoretical aspects, this study offers a promising framework by extending the prior research associating PSM and work outcomes (including work satisfaction and commitment to the organization) (Taylor, 2007, 2008; Taylor \& Westover, 2011). It is reached by putting out work outcomes as the variables intervening in the relationship between PSM and service orientation.

In addition, the current study yields a novel finding exceptionally different from previous studies in the context of business sector already examining and positioning service orientation as independent variable and job satisfaction and organizational commitment as dependent 
variable both theoretically (HennigThurau \& Thurau, 2003) and empirically (Donavan, Brown, \& Mowen, 2004; Hennig-Thurau, 2004; Kim, Leong, \& Lee, 2005). In sum, the results present a new insight into the study of human resources management in the public sector by which job satisfaction and organizational commitment should be considered as antecedents of service orientation.

This study suggests that serviceoriented employees are affected by PSM. PSM can be created if the organizations drive organizational climate attracting each employee to enhance their positive and personal motives. In the practical term, public organizations should provide an environment for the employees to maximize their contributions to the public good (Moynihan \& Pandey, 2007) and continuously socialize the values of PSM to the employees (Battaglio \& French, 2016). The diverse strategies can be considered by public managers in increasing employees' PSM, specifically for instance orientation, training, and performance measures (Jacobson, 2011; Paarlberg, Perry, \& Hondeghem, 2008).

Public organizations also accommodate PSM in the process of recruitment of civil servants to screen the employee with highly PSM (Lee \& Choi, 2016; Pandey, Wright, \& Moynihan, 2008; Taylor, Clerkin, Ngaruiya, \& Velez, 2015; Waldner, 2012). PSM can be introduced in the selection process of civil servants in the local government. The governments can adapt items of PSM, such as compassion, self-sacrifice, patriotism, attraction to the policymaking as a question in the test of public servants.

\section{CONCLUSION}

Based upon the analysis and explanation offered in this paper, the current study provides a further investigation of the link between PSM and the service orientation of public servants in the local government. It also provides mediation hypotheses to corroborate the relationship, with partial mediation of work satisfaction and organizational commitment. The present study contributes to the body of knowledge about PSM by recognizing job satisfaction and organizational commitment to elevating service orientation. It yields several suggestions to the local government in enhancing the service orientation of the public employees as well as.

\section{ACKNOWLEDGEMENT}

This material is based upon work supported by the students of Research Methods in Public Administration class of 2018/2019 academic year at the Department of Public Administration Faculty of Social and Political Sciences Universitas Maritim Raja Ali Haji. Therefore, the author is hugely indebted to the students engaged in the process of gathering the data and heated discussion in the class. The author also would like to thank the editor and three anonymous reviewers for the valuable comments and feedback on the manuscript.

\section{REFERENCES}

Allen, N. J., \& Meyer, J. P. (1990). The measurement and antecedents of affective, continuance and normative commitment to the organization. Journal of Occupational Psychology, 63(1), 118.

Andersen, L. B., Bjørnholt, B., Bro, L. L., \& Holm-Petersen, C. (2018). Leadership and motivation: A qualitative study of transformational leadership and public service motivation. International Review of Administrative Sciences, 84(4), 675 $-691$.

Andersen, L. B., \& Kjeldsen, A. M. (2013). 
Available Online at https://journal.unismuh.ac.id/index.php/otoritas

Otoritas : Jurnal Ilmu Pemerintahan, 9 (2), October 2019, 173

Public service motivation, user orientation, and job satisfaction: A question of employment sector? International Public Management Journal, 16(2), 252-274.

Andersen, L. B., Pallesen, T., \& Salomonsen, H. H. (2013). Doing good for others and/or for society? The relationships between public service motivation, user orientation and university grading. Scandinavian Journal of Public Administration, 17(3), 23-44.

Andersen, L. B., \& Pedersen, L. H. (2012). Public service motivation and professionalism. International Journal of Public Administration, 35 (1), 46-57.

Anderson, J. C., \& Gerbing, D. W. (1988). Structural equation modeling in practice: A review and recommended two-step approach. Psychological Bulletin, 103(3), 411 $-423$.

Bagozzi, R. P., \& Yi, Y. (1988). On the evaluation of structural equation models. Journal of the Academy of Marketing Science, 16(1), 74-94.

Baron, R. M., \& Kenny, D. A. (1986). The moderator-mediator variable distinction in social psychological research: Conceptual, strategic, and statistical considerations. Journal of Personality and Social Psychology, 51(6), 1173-1182.

Battaglio, R. P., \& French, P. E. (2016). Public service motivation, public management reform, and organizational socialization: Testing the effects of employment at-will and agency on PSM among municipal employees. Public Personnel Management, 45(2), 123
$-147$

Bright, L. (2007). Does personorganization fit mediate the relationship between public service motivation and the job performance of public employees? Review of Public Personnel Administration, 27(4), 361-379.

Buchanan, B. (1975). Red-tape and the service ethic: Some unexpected differences between public and private managers. Administration \& Society, 6(4), 423-444.

Caillier, J. G. (2015). Transformational leadership and whistle-blowing attitudes: Is this relationship mediated by organizational commitment and public service motivation? American Review of Public Administration, 45(4), 458475.

Castaing, S. (2006). The effects of psychological contract fulfilment and public service motivation on organizational commitment in the French civil service. Public Policy and Administration, 21(1), 84-98.

Chiang, F. F. T., \& Birtch, T. A. (2011). Reward climate and its impact on service quality orientation and employee attitudes. International Journal of Hospitality Management, 30(1), 3-9.

Chin, W. W. (1998). Commentary: Issues and opinion on structural equation modeling. MIS Quarterly, 22(1), vii $-\mathrm{xvi}$.

Chin, W. W., \& Newsted, P. R. (1999). Structural equation modeling analysis with small samples using partial least square. In R. H. Hoyle (Ed.), Statististical strategies for 
Available Online at https://journal.unismuh.ac.id/index.php/otoritas

Otoritas : Jurnal Ilmu Pemerintahan, 9 (2), October 2019, 174

small sample research. Thousand Oaks, CA: Sage Publications.

Chin, W. W., \& Todd, P. A. (2019). On the use, usefulness, and ease of use of structural equation modeling in MIS research: A note of caution. MIS Quarterly, 19(2), 237-246.

Christensen, R. K., \& Wright, B. E. (2011). The effects of public service motivation on job choice decisions: Disentangling the contributions of person-organization fit and person -job fit. Journal of Public Administration Research and Theory, 21(4), 723-743.

Clerkin, R. M., \& Coggburn, J. D. (2012). The dimensions of public service motivation and sector work preferences. Review of Public Personnel Administration, 32(3), 209-235.

Cun, X. (2012). Public service motivation and job satisfaction, organizational citizenship behavior: An empirical study based on the sample of employees in Guangzhou public sectors. Chinese Management Studies, 6(2), 330-340.

Donavan, D. T., Brown, T. J., \& Mowen, J. C. (2004). Internal benefits of service -worker customer orientation: Job satisfaction, commitment, and organizational citizenship behaviors. Journal of Marketing, 68 (1), 128-146.

Fornell, C., \& Larcker, D. F. (1981). Evaluating structural equation models with unobservable variables and measurement error. Journal of Marketing Research, 18 (1), 39-50.

Frederickson, H. G., \& Hart, D. K. (1985).
The public service and the patriotism of benevolence. Public Administration Review, 45(5), 547553.

Gerbing, D. W., \& Anderson, J. C. (1988). An updated paradigm for scale development incorporating unidimensionality and its assessment. Journal of Marketing Research, 25(2), 186-192.

Hair, J. F., Ringle, C. M., \& Sarstedt, M. (2011). PLS-SEM: Indeed a silver bullet. Journal of Marketing Theory and Practice, 19(2), 139-152.

Hayes, A. F. (2009). Beyond Baron and Kenny: Statistical mediation analysis in the new millennium. Communication Monographs, 76 (4), 408-420.

Hennig-Thurau, T. (2004). Customer orientation of service employees: Its impact on customer satisfaction, commitment, and retention. International Journal of Service Industry Management, 15 (5), 460-478.

Hennig-Thurau, T., \& Thurau, C. (2003). Customer orientation of service employees-Toward a conceptual framework of a key relationship marketing construct. Journal of Relationship Marketing, 2(1/2), 23 -41 .

Hogan, J., Hogan, R., \& Busch, C. M. (1984). How to measure service orientation. Journal of Applied Psychology, 69(1), 167-173.

Horton, S., \& Hondeghem, A. (2006). Public service motivation and commitment. Public Policy and Administration, 21(1), 1-12. 
Available Online at https://journal.unismuh.ac.id/index.php/otoritas

Otoritas : Jurnal Ilmu Pemerintahan, 9 (2), October 2019, 175

Hulland, J. (1999). Use of partial least squares (PLS) in strategic management research: A review of four recent studies. Strategic Management Journal, 20(2), 195204.

Ismail, A., \& Abd Razak, M. R. (2016). Effect of job satisfaction on organizational commitment. Management \& Marketing, 14(1), 25-40.

Jacobson, W. S. (2011). Creating a motivated workforce: How organizations can enhance and develop public service motivation (PSM). Public Personnel Management, 40(3), 215-238.

Jensen, U. T., \& Andersen, L. B. (2015). Public service motivation, user orientation and prescription behaviour: Doing good for society or for the individual user? Public Administration, 93(3), 753-768.

Jin, M. H., McDonald, B., \& Park, J. (2018). Does public service motivation matter in public higher education? Testing the theories of personorganization fit and organizational commitment through a serial multiple mediation model. American Review of Public Administration, 48(1), 82-97.

Kelley, S. W. (1992). Developing customer orientation among service employees. Journal of the Academy of Marketing Science, 20(1), 27-36.

Kim, S. (2012). Does person-organization fit matter in the public sector? Testing the mediating effect of person-organization fit in the relationship between public service motivation and work attitudes. Public Administration
Review, 72(6), 830-840.

Kim, S. (2017). Comparison of a multidimensional to a unidimensional measure of public service motivation: Predicting work attitudes. International Journal of Public Administration, 40 (6), 504-515.

Kim, W. G., Leong, J. K., \& Lee, Y.-K. (2005). Effect of service orientation on job satisfaction, organizational commitment, and intention of leaving in a casual dining chain restaurant. International Journal of Hospitality Management, 24(2), 171-193.

Kjeldsen, A. M. (2012). Sector and occupational differences in public service motivation: A qualitative study. International Journal of Public Administration, 35(1), 5869.

Kjeldsen, A. M., \& Hansen, J. R. (2018). Sector differences in the public service motivation-Job satisfaction relationship: Exploring the role of organizational characteristics. Review of Public Personnel Administration, 38(1), 24-48.

Kline, R. B. (2011). Principles and practice of structural equation modeling (Third Ed.). New York: The Guilford Press.

Kock, N. (2011). Using WarpPLS in ecollaboration studies: Mediating effects, control and second order variables, and algorithm choices. International Journal ECollaboration, 7(3), 1-13.

Kock, N. (2017). WarpPLS user manual: Version 6.0. Laredo, TX: ScriptWarp Systems. 
Review of Public Personnel

Korunka, C., Scharitzer, D., Carayon, P., Hoonakker, P., Sonnek, A., \& Sainfort, F. (2007). Customer orientation among employees in public administration: A transnational, longitudinal study. Applied Ergonomics, 38(3), 307315.

Lee, G., \& Choi, D. L. (2016). Does public service motivation influence the college students' intention to work in the public sector? Evidence from Korea. Review of Public Personnel Administration, 36(2), 145-163.

Lewis, G. B., \& Frank, S. A. (2002). Who wants to work for the government? Public Administration Review, 62(4), 395-404.

Liaw, Y.-J., Chi, N.-W., \& Chuang, A. (2010). Examining the mechanisms linking transformational leadership, employee customer orientation, and service performance: The mediating roles of perceived supervisor and coworker support. Journal of Business Psychology, 25 (3), 477-492.

Liu, B., Tang, T. L.-P., \& Yang, K. (2015). When does public service motivation fuel the job satisfaction fire? The joint moderation of person-organization fit and needs -supplies fit. Public Management Review, 17(6), 876-900.

Moynihan, D. P., \& Pandey, S. K. (2007). The role of organizations in fostering public service motivation. Public Administration Review, 67(1), 40-53.

Naff, K. C., \& Crum, J. (1999). Working for America: Does public service motivation make a difference?
Administration, 19(4), 5-16.

Paarlberg, L. E., Perry, J. L., \& Hondeghem, A. (2008). From theory to practice: Strategies for applying public service motivation. In J. L. Perry \& A. Hondeghem (Eds.), Motivation in public management: The call of public service (pp. 268-293). Oxford: Oxford University Press.

Pandey, S. K., Wright, B. E., \& Moynihan, D. P. (2008). Public service motivation and interpersonal citizenship behavior in public organizations: Testing a preliminary model. International Public Management Journal, 11(1), 89-108.

Park, S. M., \& Word, J. (2012). Driven to service: Intrinsic and extrinsic motivation for public and nonprofit managers. Public Personnel Management, 41(4), 705 -735 .

Perry, J. L. (1996). Measuring public service motivation: An assessment of construct reliability and validity. Journal of Public Administration Research and Theory, 6(1), 5-22.

Perry, J. L. (1997). Antecedents of public service motivation. Journal of Public Administration Research and Theory, 7(2), 181-197.

Perry, J. L., \& Wise, L. R. (1990). The motivational bases of public service. Public Adminstration Review, 50(3), 367-373.

Potipiroon, W., \& Ford, M. T. (2017). Does public service motivation always lead to organizational commitment? Examining the moderating roles of intrinsic 
Available Online at http://journal.unismuh.ac.id/index.php/otoritas

Otoritas : Jurnal Ilmu Pemerintahan, 9 (2), October 2019, 177

motivation and ethical leadership.

Public Personnel Management, 46 (3), 211-238.

Potipiroon, W., Srisuthisa-ard, A., \& Faerman, S. (2019). Public service motivation and customer service behaviour: Testing the mediating role of emotional labour and the moderating role of gender. Public Management Review, 21(5), 650668.

Rainey, H. G. (1982). Reward preferences among public and private managers: In search of the service ethic. American Review of Public Administration, 16(4), 288-302.

Ritz, A. (2011). Attraction to public policy making: A qualitative inquiry into improvements in PSM measurement. Public Administration, 89(3), 1128-1147.

Sayce, S. (2016). Public service motivation for executive pension trutees: A qualitative study. International Public Management Review, 17(1), 21-39.

Schott, C., Steen, T., \& Van Kleef, D. D. (2019). Reality shock and public service motivation: A longitudinal, qualitative study among Dutch veterinary inspectors. International Journal of Public Administration, 42(6), 468-481.

Shrestha, A. K., \& Mishra, A. K. (2015). Interactive effects of public service motivation and organizational politics on Nepali civil service employees' organizational Commitment. Business Perspectives and Research, 3(1), 21-35.

Spector, P. E. (1985). Measurement of human service staff satisfaction:
Development of the job satisfaction survey. American Journal of Community Psychology, 13(6), 693-713.

Steijn, B., \& Leisink, P. (2006). Organizational commitment among Dutch public sector employees. International Review of Administrative Sciences, 72(2), 187 $-201$.

Susskind, A. M., Kacmar, K. M., \& Borchgrevink, C. P. (2003). Customer service providers' attitudes relating to customer service and customer satisfaction in the customer-server exchange. Journal of Applied Psychology, 88 (1), 179-187.

Taylor, J. (2007). The impact of public sector motives on work coutcomes in Australia: A comparative multidimensional analysis. Public Administration, 85(4), 931-959.

Taylor, J. (2008). Organizational influences, public service motivation and work outcomes: An Australian study. International Public Management Journal, 11(1), 67-88.

Taylor, J. (2014). Public service motivation, relational job design, and job satisfaction in local government. Public Administration, 92(4), 902-918.

Taylor, J. K., Clerkin, R. M., Ngaruiya, K. M., \& Velez, A. L. K. (2015). An exploratory study of public service motivation and the institutionaloccupational model of the military. Armed Forces and Society, 41(1), 142-162.

Taylor, J., \& Westover, J. H. (2011). Job 
Available Online at http://journal.unismuh.ac.id/index.php/otoritas

Otoritas : Jurnal Ilmu Pemerintahan, 9 (2), October 2019, 178

satisfaction in the public service: The effects of public service motivation, workplace attributes and work relations. Public Management Review, 13(5), 731751.

Van der Wal, Z. (2015). "All quiet on the non-Western front?" A review of public service motivation scholarship in non-Western contexts. Asia Pacific Journal of Public Administration, 37(2), 6986.

Vandenabeele, W. (2009). The mediating effect of job satisfaction and organizational commitment on self -reported performance: More robust evidence of the PSMperformance relationship. International Review of Administrative Sciences, 75(1), 1134.

Waldner, C. (2012). Do public and private recruiters look for different employees? The role of public service motivation. International Journal of Public Administration, 35 (1), 70-79.

Williams, L. J., Edwards, J. R., \& Vandenberg, R. J. (2003). Recent advances in causal modeling methods for organizational and management research. Journal of Management, 29(6), 903-936.

Wright, B. E., \& Pandey, S. K. (2008). Public service motivation and the assumption of personorganization fit: Testing the mediating effect of value congruence. Administration \& Society, 40(5), 502-521.

Xiaohua, L. (2008). An empirical study on public service motivation and the performance of government employee in China. Canadian Social Science, 4(2), 18-28.

Yudiatmaja, W. E. (2012). Dinamika administrasi negara kontemporer: Konsep dan isu [The Dynamics of contemporary public administration: Concepts and issues]. Yogyakarta: Capiya Publishing.

Yudiatmaja, W. E. (2017). Public service motivation differences between permanent and contract employees in the local government. Mimbar: Jurnal Sosial Dan Pembangunan, 33(2), 329340. 